\title{
TANTANGAN DAN KESEMPATAN DALAM \\ TUGAS PENGGEMBALAAN GEREJA \\ DI ERA POS MODERNISME
}

\author{
Yohanis Luni
}

\section{Intisari}

Gereja ditantang untuk ambil bagian dalam mengobarkan panggilannya melalui koinonia, diakonia, dan marturia. Panggilan ini tidak pernah berubah sepanjang zaman. Ini pula yang harus mewarnai penggembalaan gereja. Namun, setiap zaman memiliki konsep, pandangan, nilai-nilai, dan sistem yang berbeda. Sering kali Gereja mulai terbawa oleh arus zaman sehingga dogma gereja menjadi porak poranda oleh pikiran zaman. Agar gereja mampun menghadapi tantangan zaman maka ketangguhan dan konsistensi teologi yang benar yang berpusat pada Allah melalui firman Allah yang hidup dan kekal harus menjadi dasar bagi pelayanan penegembalan di era pos modernisme ini. tergoncangkan.

\section{Pendahuluan}

Istilah post modern ${ }^{2}$ dalam tulisan ini tidaklah dimaksudkan untuk dimengerti sebagai isme atau paham, tetapi dimengerti sebagai gejala diau fenomena yang terus mempengaruhi seluruh aspek kehidupan manusia Zaman ini. Seperti yang dijelaskan oleh Stanley J. Grenz bahwa belakangan ini pola pikir post modern terwujud dalam banyak aspek kebudayaan, termasuk arsitektur, seni, dan drama. Kita dapat mencium gejala pergeseran dari modern kepada post modern dalam budaya pop, khususnya video musik sampai kepada Seritil Star Trek. ${ }^{3}$ Pada dasarnya "post modern atau zaman setelah modern" muncul sebagai rfaksi terhadap fakta tidak tercapainya impian yang dicita-citakan dalam era modern. Era modern muncul dan berkembang sejak abad pertengahan sampai abad ke-18, dan mencapai puncaknya pada abad ke-19 sampai awal abad ke-20 yang memiliki cita-cita yang tersimpul dalam lima kata yaitu reason (rasio), nature (alam), happiness (kebahagiaan), progress (kemajuan), dan liberty (kebebasan).
Pada masa sekarang nyata terliha: bahwa ilmu pengetahuan dan teknologi yang merupakan wujud nyata cita-cita modern tidak dapat memecahkan semua masalah manusia. Keduanya memang maju secara pesat, tetapi kemajuan tersebut seolah-olah justru memberi peluang yang semakin besar bagi manusia untuk menghancurkan dirinya sendiri, seperti polusi yang hebat, pencemaran lingkungan secara besar-besaran, eksploitasi tenaga kerja, imperialisme, kolonialisme, dan tribalisme. Karena itu muncullah orangorang post modern yang memberikan reaksi keras terhadap modernisme.

Gejala post modern menarik untuk disimak dengan cirinya di mana orang akan semakin menghargai spiritualitas tanpa harus religius. "Mereka mencari keterlibatan spiritual yang lebih dalam di dunia ini tanpa terikat pada guru, medium, atau pengganti lain bagi kreatifitas individual mereka sendiri." 4 Selain itu ciri lain dari post modern adalah menghargai kepelbagaian. Di sini terdapat prinsip filsafat relativisme. Trend lain bagi masyarakat post modern adalah tersedianya informasi- 
informasi yang di posting di cyber-net sehingga belajar secara mandiri atau autodidact dapat dilakukan dengan mudah. Dalam konteks gereja munculnya cyberchurch atau electronic church sebagai hasil dari sistem teknologi mutakhir. Bukankah gejala semacam ini merupakan tantangan (challenge), dan kesempatan (opportunity) dalam pelaksanaan tugas penggembalaan gereja sekarang ini?

\section{Tantangan dan Kesempatan}

Di satu pihak post modern telah memberikan kesempatan bagi eksistensi kekristenan yang telah terkikis habishabisan di era modernisme. Hal ini dimungkinkan oleh hadirnya post modern dengan filsafat relativisme radikalnya yang justru mengakui kebenaran yang terdapat di dalam kekristenan. Selain itu, hal yang menarik adalah masyarakat post modern sangat haus dengan persekutuan sejati (penekanan pada komunitas), maka pendekatan dengan menyajikan kehangatan persaudaraan Kristen (koinonia) dapat membawa mereka bertemu dengan Kristus. Strategi kelompok kecil dalam penggembalaan sangat efektif diterapkan dalam konteks ini. Meningkatnya penghargaan terhadap spiritualitas juga merupakan kesempatan yang sangat efektif bagi penggembalaan gereja melalui metode konseling.

Namun, di sisi lain hadirnya post modern menimbulkan tantangan yang tidak mudah bagi kekristenan, bahkan lebih berbahaya ketimbang era modernisme. Mari kita melihat secara jelas beberapa tantangan yang ditimbulkan oleh post modern bagi tugas penggembalaan gereja. ${ }^{5}$ Dengan mengacu kepada dekonstruksionisme (kebenaran yang subjektif sebagai hasil bentukan yang diungkapkan melalui deskripsi manusia) dan relativisme radikal, dalam dua bidang utama yang berkaitan dengan tugas penggembalaan yaitu penyampaian Firman dan moral etika.

\section{Tantangan Bagi Penyampaian Firman}

Amatlah terasa bahwa diakhirakhir ini, fokus dan gaya pelayanan gereja mulai bergeser dengan menampilkan nuansa yang baru. Umumnya para gembala (pastor), para pemimpin gereja, dan atau para rohaniwan lebih menerima perubahan tanpa selektif daripada mempertimbangkannya. Menurut pendapat penulis, ini dapat menghancurkan gereja yang sejati. Gejala-gejala yang ditimbulkan oleh post modern yang mewarnai dinamika pelayanan gereja sekarang ini dalam hal pemberitaan Firman Tuhan adalah sebagai berikut:

Pertama, presentasi sebagai ganti esensi. Orang-orang post modern tidak mencari esensi, karena bagi mereka tidak akan pernah diketahui secara pasti. Karena itu bagi mereka penyampaian Firman yang penting adalah presentasinya atau actingnya, atau dengan kata lain penyampaian hal-hal dipermukaan saja bukan substansinya atau yang hakiki. Hal ini telah menghasilkan pudarnya kebenaran (truth decay) Kristen yang sejati. Pemberitaan hanya berfokus pada kebutuhan manusia (needs people) secara horizontal dan mengesampingkan sumber vertikal yang seharusnya lebih utama dari pada segalanya. Banyak orang Kirsten yang tidak lagi menyukai khotbah-khotbah doktrinal, tetapi lebih menyukai khotbah yang dapat menyentuh emosionalnya saja.

Kedua, tafsir alternatif sebagai ganti dogma. Orang-orang Kristen post modern menilai bahwa kekristenan terlalu menekankan keterikatan pada dogmadogma hasil perumusan gereja abad-abad awal di Barat. Tidaklah mengherankan jikalau belakangan ini muncul berbagai dobrakan terhadap dogma-dogma gereja. Seperti munculnya teologi pembebasan yang menilai bahwa kekristenan telah bersifat terlalu berpusat pada Barat dan 
tidak praktis. Sedangkan para kaum feminis melihat bahwa sifat paternalistic terlalu dominan dalam teologi Kristen. Demikian pula munculnya teologi hitam (black theology) adalah untuk memberikan alternatif bagi teologi yang dinilai tidak menyentuh kehidupan mereka. Munculnya gerakan-gerakan tersebut bagi Hans Kung seorang teolog Katholik Jerman memperjelas ciri-ciri post modern yang menekankan pluralitas, polisentris, praksis, fungsional, dan pembebasan.

Ketiga, ortopraksis sebagai ganti ortodoksi. Pengajaran yang bersifat praktis (ortopraksis) pada dasarnya memang dituntut dari suatu ajaran, khususnya dalam kekristenan. Adalah hal yang wajar apabila seseorang merasa enggan untuk mempelajari sebuah sistem pengajaran (ortodoksi) yang tidak bersentuhan dengan realita sehari-hari. Keduanya harus seimbang. Namun di dalam era post modern, ortopraksis jauh lebih ditekankan ketimbang ortodoksi, bahkan kalau bisa ortodoksi dibuang saja. Itulah sebabnya sering kali banyak orang mengungkapkan, "tidak perlu yang teologis, yang praktis saja." Ini dapat mengindikasikan bahwa konsep orang-orang post modern terhadap pengajaran bersifat self interest (yang berpusat pada diri sendiri) bukan pada Allah

Sebagai contoh, saat kita mengajarkan tentang Yesus adalah Tuhan tidak perlu dipermasalahkan tentang keilahian dan kemanusiaan-Nya, pribadi kedua dari Allah Tritunggal, tidak perlu memperhitungkan yang bersifat dogmatis, yang penting adalah apakah Yesus menyembuhkan atau tidak? Memberikan kelegaan atau tidak? Menguatkan perasaan atau tidak? Hal ini sangat membahayakan kehidupan kekristenan yang sejati.

Keempat, produksi makna sebagai ganti objektivitas penafsiran. Penafsiran yang ditunjukkan melalui literatur-literatur dan khotbah-khotbah telah menonjolkan produksi makna. Gaya penafsiran melalui studi gramatika historis sudah mulai ditingggalkàn dengan alasan tidak realistis dan mengisolasi teks. Lebih berbahaya lagi apabila pemberitaan gereja sudah dipengaruhi oleh salah seorang tokoh hermeneutika post modern, Hans Georg Gadamer yang mengusulkan empat hal bagi penc.fsiran; (1) dihapuskannya segala bentuk model pendekatan dalam penafsiran. Alasannya kebenaran akan diperoleh apabila batas-batas metodologi dilampaui, dengan membiarkan tiap-tiap orang menemukan kebenarannya sendiri; (2) dalam menafsirkan teks, seseorang harus membiarkan prasangkanya ikut berperan, karena berita sebuah teks sematamata bukan dari teks, melainkan peleburan antara teks dan prasangka kita; (3) tidak pernah ada pemahaman hasil yang bersifat objektif, sebab pemahaman selalu berkaitan dengan keadaan di mana kita berada, kapan, dan kondisi bagaimana; (4) seorang penafsir harus terbuka terhadap pengalaman baru, tidak terikat pada kebenaran statis dan dogmatik.

Berangkat dari hermeneutikanya Gadamer atau para post modernist lainnya, cobalah kita renungkan sejenak, masihkah tugas penggembalaan sejati mewarnai pengajaran gereja? Atau gereja sudah terbawa arus post modernist tersebut? Menyedihkan sekali! Bayangkan di dalam gereja tidak akan didapati kebenaran mutlah dan universal. Dogma gereja tidak akan pernah tetap, tetapi beritanya berubah mengikuti arus Zaman dunia ini. Tidaklah mengherankan apabila paradigma penggembalaan mengalami pergeseran dari gaya hidup bersahaja menjadi gaya hidup mewah (lux) demikian juga dari konsep berteologi konseptual menjadi mistikal, esensi menjadi presentasi, dogmatis menjadi alternatif, dan objektif menjadi produksi makna, bahkan masih banyak hal lain yang tampak dalam gaya pelayanan gereja sekarang ini sebagai pengaruh post modern. 


\section{Tantangan Bagi Moral-Etika}

Post modern juga ditandai dengan runtuhnya nilai-nilai moral. Gene Veith mengatakan,

Today religion is not seen as a set of beliefs about what is real and what is not. Rather, religion is seen as preference, a choice. We believe in what we like. We believe what we want to believe... Where there are no absolute truths, the intellect gives over to the will. Aesthetic criteria replace rational criteria. ${ }^{6}$

Pernyataan di atas amat menyedihkan, bahkan merupakan pernyataan yang merendahkan kekristenan yang meyakini adanya kebenaran mutlak, objektif yang mempunyai otoritas dari Allah. Karena itu, orang Kristen perlu mengantisipasi secara tepat pengaruh post modern yang amat berbahaya tersebut. Blamires menulis,

Pemikiran pasca-Kristen secara alamiah akan cenderung mendiskreditkan kekristenan. Merupakan kelemahan setiap manusia bahwa kita semua suka merasa bahwa kita mengikuti zaman up to date dan tidak terikat pada ide-ide usang... kita orang Kristen harus lebih waspada terhadap sodokan licik bagi kepercayaan Kristen yang berlangsung di media, yang ditudungi oleh komentar yang tampaknya objektif di dalam dunia seni dan kehidupan publik secara umum. ${ }^{7}$

Kiranya komentar di atas memberikan nasihat tegas kepada kekristenan untuk tetap berada pada keyakinan Kristen yang sejati yang tidak bisa digeser oleh perubahan zaman yang silih berganti. Berkaitan dengan moral etika, pada era post modern yang terkenal dengan relativismenya telah menghasilkan moral chaos, sebab semua pertimbangan moral dikembalikan kepada individu atau kelompok. Tidak ada prinsip dan nilai kebenaran moral secara universal dan mutlak. Bahkan dalam ruang lingkup yang sangat sempit, seperti keluarga, keputusan moral harus dapat dikembalikan kepada tiap-tiap individu.

Lantaran tidak ada objektivitas kebenaran tentang apa yang baik dan yang jahat, maka dalam tindakan moral yang mereka tekankan bukan apa yang benar atau salah, melainkan dasar pertimbangannya adalah hal-hal yang sangat praktis dar subjektif. Misalnya, dalam kasus euthanasia, aborsi, atau perceraian, tidak perlu lagi dipusingkan soal dogma gereja, namun yang penting adalah dipertimbangkan berdasarkan hal-hal yang praktis. Fenomena ini merupakan tantangan dan kesempatan terbesar pelaksanaan tugas penggembalaan gereja yang harus dipikirkan secara serius dan intensitas yang tinggi.

\section{Beberapa Prinsip dalam Pelaksanaan Tugas Penggembalaan Gereja}

Dalam bagian ini penulis, akan memberikan beberapa prinsip mengenai tugas atau praktik penggembalaan yang seharusnya menjadi fokus perhatian gereja zaman ini. Meskipun apa yang akan dikemukanan amat praktis dan sederhana, kiranya dapat membuka wawasan para pembaca untuk dapat meningkatkan tanggung jawab dalam tugas penggembalaan gereja.

\section{Perkunjungan yang berfokus pada Intensitas bukan Frekuensi}

Apabila kita membicarakan penggembalaan dalam konteks gereja amat akrab dengan istilah perkunjungan. Pada kenyataannya perkunjungan merupakan prinsip yang esensial dalam melaksanakan tugas penggembalaan yang sangat dibutuhkan jemaat. Namun seiring dengan perubahan zaman yang terus bergulir, di era komunikasi dan informasi yang sudah sangat maju disertai dengan kesibukan masyarakat yang tinggi telah menjadi kesulitan tersendiri dalam pelaksanaan perkunjungan. 
Dalam bagian ini penulis bermaksud memberikan penekanan perkunjungan bukan pada frekuensi, melainkan intensitas atau kualitasnya. Berdasarkan pengamatan penulis, banyak gereja yang memiliki masalah dalam penggembalaan, khususnya dalam hal perkunjungan. Ada gembala (pastor) yang hanya mengunjungi orang tertentu, sehingga yang lain terabaikan. Selain itu gereja yang mempunyai jumlah anggota yang banyak menyebabkan tidak maksimalnya pelaksanaan perkunjungan sehingga beberapa anggota jemaat-Nya menjadi kecewa. Perkunjungan terhadap jumlah anggota yang banyak karena terbatasnya waktu dan kesempatan bu-kanlah masalah yang menyebabkan penggembalaan menjadi stagnant, jika itu dilakukan dengan intensitas.

Begitu banyak orang yang sungguh-sungguh tersentuh secara mendalam oleh perjumpaan dengan Yesus. Ketika Yesus berkunjung ke rumah mertua Petrus yang sakit demam (Mat 8:14-17; Luk 4:3841) hasilnya luar biasa, Ia membuahkan spontanitas; perempuan itu segera bangun dan melayani mereka" (Luk 4:39). Mertua Petrus terkesan dengan penampilan dan ketulusan Yesus, sehingga ia pun melayani dengan ketulusan. Pelayanan Yesus mempunyai ciri khas yang sangat menarik. Apa yang menarik perhatian banyak orang kepada pelayanan Yesus? Rick Warren berkata,

Yesus berbuat tiga hal dengan orang banyak: Ia mengasihi mereka (Mat. 9:36), Ia memenuhi kebutuhan mereka (Mat 15:30; Luk 6:17-18; Yoh 6:2), dan Ia mengajar mereka dengan cara-cara yang menarik dan praktis (Mat 13:34; Mark 10:1; 12:37). Tiga unsur yang sama ini akan menarik banyak orang pada masa kini. ${ }^{8}$

Alkitab memberitahukan kepada kita bahwa ke mana pun Yesus berkunjung atau "berkeliling" Ia selalu menjadi perhatian banyak orang. Ini prinsip yang sa- ngat mendasar yang seharusnya diteladani dalam praktek penggembalaan masa kini. Jadi, kata kunci perkunjungan yang efektif adalah perkunjungan yang dilakukan dengan intensitas melalui kesungguhan dan ketulusan hati. Bukankah itu yang Yesus lakukan sebagai gembala agung yang harus menjadi teladan bagi kita? Ketulusan menjadi rahasia yang paling pokok dan dapat menjamin efektivitas perkunjungan penggembalaan dalam lingkungan atau zaman yang berubah.

\section{Membangun Kehangatan Dalam Komunikasi}

Rahasia penggembalaan yang sangat mendasar adalah komunikasi. Bagian ini mungkin agak sulit untuk dijelaskan, tetapi ini masalah praktis. Singkatnya, ada kalanya kita sangat terkesan oleh seseorang yang meskipun kita baru mengenalnya, namun ia memancarkan kehangatan dalam tutur katanya yang indah dan penuh makna. Orang yang menunjukkan kehangatan menjauhkan kita dari rasa kebosanan, malahan kita merasa aman di dekatnya. Selain itu, kita bangga berkenalan dan berkomunikasi dengannya.

Tetapi sebaliknya bayangkan jika kita harus bertemu dengan orang yang kesan pertamanya sudah membosankan, yang hanya membeberkan kehebatannya dan tidak memberikan kesempatan kepada lawan bicaranya untuk mengatakan sesuatu, begitu membosankan bertemu dengan orang yang demikian. Betapa sulitnya juga apabila kita bertemu dengan orang pendiam, sulit bicara. Jika ini yang terjadi, sulit untuk membangun kehangatan. Itu sebabnya dalam rahasia hubungan adalah terciptanya komunikasi yang menunjukkan kehangatatan, ketulusan, makna, kejujuran, dan keterbukaan dengan segala kerendahan hati.

Dalam teori komunikasi dikenal dua bentuk komunikasi yaitu komunikasi verbal dan komunikasi nonverbal. Dalam A Dictionary of Pastoral Care dijelaskan 
Verbal communication consists of the use of language, usually in conversa-tion, but also in speeches, over the telephone and via writing. The basic types of utterance are (a) asking ques-tions, $(b)$ giving orders or instructions, (c) providing information... Nonverbal communication is the use of face, tone of voice, and other bodily signals, to send information either in combination with language, or alone. ${ }^{9}$

Kedua bentuk komunikasi tersebut amat penting dalam praktek penggembalaan. Keterampilan dan ketulusan dalam berkomunikasi dengan orang lain sebagai rahasia terciptanya kehangatan, kepercayaan dan kenyamanan (comfortable). Mengacu pada kerangka teori John Powel yang membagi komunikasi dalam lima tahap: (1) tahap sekedar basa-basi; (2) tahap mempergunjingkan objek atau orang lain tanpa keterlibatan pribadi para subjek; (3) tahap percakapan pada dataran rasional; (4) tahap berbagi rasa yang melibatkan emosiperasaan; (5) tahap puncak (peak experiences). ${ }^{10}$

Pada tiap aras komunikasi di atas, tersirat pengenalan, hanya saja berbeda bobot atau maknanya. Marilah kita berkonsentrasi sejenak akan praktek yang dilakukan Yesus Gembala Agung kita, saat Ia mengatakan,

Akulah gembala yang baik dan Aku mengenal domba-domba-Ku dan domba-domba-Ku mengenal Aku, sama seperti Bapa mengenal Aku dan Aku mengenal Bapa, dan Aku memberikan nyawa-Ku bagi dombadomba-Ku. (Yohanes 10:14, 15).

Istilah $\gamma \iota v \omega \sigma \kappa \omega$ dalam ayat ini artinya memahami, mengenal secara mendalam, mempelajari, menerima, merasakan, dan mengakui keberadaannya. Dalam konteks ini terkandung makna komunikasi yang dalam antara Gembala Agung dan domba-Nya, di mana gembala mengenal domba-domba-Nya demikian sebaliknya domba-domba-Nya mengenal-
Nya. Berkaitan dengan tahap komunikasi yang dikemukakan oleh John Powell di atas, pastilah Yesus tidak berada pada urutan kedua atau ketiga, tetapi pada urutan keempat dan kelima. Untuk menjelaskan istilah mengenal, Joni Eareckson Tada mengatakan, "Ketika kehidupan menyenangkan kita mungkin meluncur lewat dengan mengetahui tentang Yesus, meniru Dia dan mengutip perkataan-Nya serta membicarakannya. Tetapi hanya dalam penderitaan kita akan mengenal Yesus."

Stephen R. Covey seorang penulis dan pembicara terkenal memberikan komentar mengenai prinsip komunikasi dalam satu ungkapan, "berusaha mengerti lebih dahulu, barulah dimengerti"11 Komunikasi adalah keterampilan yang paling penting di dalam kehidupan dan kelihatannya inilah yang diperagakan Yesus sebagai gembala yang baik seperti yang dikisahkan Yohanes. Ini juga yang harus mewarnai tugas penggembalaan kita yaitu mengenal dan mengerti orang lain.

\section{Mengembangkan Hubungan yang Dialogis}

Fenomena penggembalaán yang mendominasi kehidupan gereja adalah sang gembala (pastor) hanya menempatkan dirinya sebagai subjek dan menempatkan jemaat sebagai objek dalam praktek penggembalaannya. Hubungan yang dialogis dalam tugas penggembalaan tidak mungkin terjalin tanpa prinsip subjek dan subjek atau subjek dengan kebersamaan. Dalam rangka pertukaran informasi (sharing) kita harus menempatkan orang lain sejajar dengan kita, sehingga kita dapat membangun keakraban, keterbukaan, dan kejujuran. Inilah yang dimaksudkan mengembangkan hubungan yang dialogis dalam penggembalaan. Prinsip ini yang menjiwai pernyataan Tuhan Yesus yang dikisahkan dalam Injil Yohanes 15:15 ketika Ia mengatakan, 
Aku tidak menyebut kamu lagi hamba, sebab hamba tidak tahu, apa yang diperbuat oleh tuannya, tetapi Aku menyebut kamu sahabat, karena Aku telah memberitahukan kepada kamu segala sesuatu yang telah Kudengar dari Bapa-Ku.

Istilah sahabat dalam kalimat di atas dalam bahasa Yunani $\phi i \lambda o \zeta$ berarti, kesetaraan, keramahan atau hubungan yang akrab dengan orang lain ${ }^{12}$. Istilah ini sama dengan istilah 'bersahabat' yang terdapat dalam Kisah Para Rasul 19:31. Dari sini kita mengerti bahwa sahabat berarti menempatkan satu dengan yang lain pada dataran yang sama. Hal ini juga seharusnya menjadi gaya hidup hubungan antara guru dan murid, dosen dengan mahasiswa dalam konteks pendidikan teologi.

Dalam mengembangkan hubungan yang dialogis berarti melibatkan perhatian, memberikan hati yang melambangkan hidup kita. Diri kita adalah karunia dari Tuhan. Istilah memberikan hati telah diajarkan lebih dahulu oleh Yesus Kristus yang dikaitkan dengan kasih persahabatan, ketika Ia berkata; Tidak ada kasih yang lebih besar dari pada kasih seorang yang memberikan nyawanya untuk sahabatsahabatnya (Yohanes 15:13). Hubungan bertitik tolak dari kasih dalam tindakan (action point), bukan kasih yang hanya diungkapkan (talking point).

\section{Menjaga Konfidensialitas}

Prinsip ini merupakan prinsip penting yang harus ditegaskan yang sering kali menjadi faktor kegagalan dalam praktik atau tugas penggembalaan gereja. Konfidensialitas adalah hal-hal yang bersifat rahasia pribadi yang diungkapkan kepada orang lain atas dasar kepercayaan. Namun sering terjadi bahwa dalam penggembalaan banyak tukang gossip professional yang suka membeberkan rahasia orang lain dan ini tidak mustahil terjadi bagi para gembala (pastor), atau istri gembala, sehingga banyak orang menjadi malu dan kecewa.

Kalau konfidensialitas rusak, hilanglah kepercayaan terhadap kita, rusaklah hubungan persahabatan yang dibangun. Hal ini berkaitan dengan accountability yaitu dapat dipertanggungjawabkan, dapat dipercaya, dan dapat diandalkan. Mengenai masalah ini, Rick Warren memberikan komentar dengan sangat jelas dengan mengatakan,

Hanya dalam lingkungan yang aman di mana ada penerimaan yang hangat dan sikap memegang rahasia yang dapat dipercaya, orang-orang akan terus terang serta menyampaikan berbagai luka hati, kebutuhan, dan kesalahan terdalam mereka... sikap kita memegang rahasia berarti apa yang disampaikan dalam kelompok anda hanya untuk kelompok anda, bukan menggosipkannya dengan orang lain. ${ }^{13}$

Allah berfirman, "Gosip disebarkan oleh orang-orang yang jahat; mereka menimbulkan kesulitan dan menceraikan sahabat yang karib."14 Gosip selalu menyebabkan sakit hati dan perpecahan, menghancurkan persekutuan, serta menghancurkan pelayanan. Hal ini harus diperhatikan dalam tugas penggembalaan gereja. Menjaga dan memelihara konfidensialitas membutuhkan bijaksana dari Tuhan. Sikap hati-hati dan mengekang diri dan menolak mendengarkan gosip merupakan rahasia terpeliharanya konfidensialitas dalam pelaksanaan tugas pastoral gereja dalam menghadapi tantangan zaman yang multidimensial.

\section{Pergeseran Nilai: Tantangan dan Kesempatan Penggembalaan?}

Setiap zaman memiliki konsep, pandangan, nilai-nilai, dan sistem yang berbeda. Sering kali Gereja mulai terbawa oleh arus Zaman sehingga dogma gereja 
menjadi porak poranda oleh pikiran zaman yang menghasilkan teologi yang berubahubah. Mau dibawa ke manakah gereja? Camkanlah ini! Sejarah telah membuktikan bahwa teologi yang dipengaruhi oleh pikiran zaman secara praktis tampaknya lebih sesuai dengan zaman itu, namun segera akan diubah oleh zaman berikutnya. Ketangguhan dan konsistensi teologi yang benar yang berpusat pada Allah melalui firman Allah yang hidup dan kekal selamanya tidak akan pernah tergoncangkan.

Bukankah sejarah membuktikan bahwa teologi Kristen telah mengalami gelombang ujian dari abad ke abad, baik dari zaman pencerahan (abad 17-18), zaman Ideologis (abad 19) maupun zaman modern atau zaman analis dan informasi (abad 20), dan sekarang kita masuk di era post modern (abad 21)? Masihkah gereja konsisten terhadap tugas penggembalaanNya? Sungguh menggelikan bahwa banyak konsep di akhir-akhir ini berembelembel "inovatif" atau "mutakhir" yang telah mempengaruhi gereja secara berlebihan yang sebenarnya bukanlah hal baru karena hal itu pun telah digunakan pada masa lampau dalam bentuk yang bervariasi. Memang, segala sesuatu tampaknya baru, jikalau Anda tidak mengetahui tentang sejarah. Itulah sebanya Hegel berkata, "Pengajaran terbesar dari sejarah adalah manusia tidak menerima pelajaran sejarah."

Memang harus disadari bahwa tugas penggembalaan gereja sering kali mengalami deklinasi dan stagnasi karena gereja kurang mengantisipasi perubahan dunia. ${ }^{15}$ New form technology artinya: gereja kurang memanfaatkan teknologi untuk pelayanan. Globalization artinya gereja tertutup dan hanya menjangkau orang tertentu saja dalam masyarakat. Namun. dalam perubahan zaman bagaimana pun gereja dipanggil untuk mewujudkan tanggung jawab penggembalaan secara konsistensi yang bertitik tolak dari nilai- nilai yang kita warisi dari Yesus Kristus melalui kasih pengorbanan yang diwujudkan-Nya dalam hidup, pelayanan penggembalaan-Nya, kematian dan kebangkitan-Nya. Masalah krusial yang melanda gereja zaman ini merurut pendapat penulis adalah pudarnya nilainilai harmoni digantikan oleh arogansi dan kompetitif yang egois, kurangnya rasa kepedulian sosial, kebersamaan, dan penghargaan, serta meningkatnya kemerosotoan moral. Inilah tantangan dan kesempatan yang harus menjadi tanggung jawab penggembalaan gereja. Bukankah Yesus telah memperagakan tugas penggembalaan sejati untuk menjadi teladan bagi kita?

\section{Kesimpulan}

Gereja ditantang untuk ambil bagian dalam mengobarkan panggilannya melalui koinonia, diakonia, dan marturia. Panggilan ini tidak pernah berubah sepanjang zaman. Ini pula yang harus mewarnai penggembalaan gereja. Oleh karena itu mengacu kepada cara gereja dalam menghadapi tantangan zaman, maka penulis berpedoman kepada apa yang diuraikan oleh John Stott dalam bukunya Isu-Isu Global yang menyarankan agar gereja mempunyai lima dasar yang dipakai untuk menghadapi tantangan zaman.

Pertama, doktrin yang lebih genap tentang Allah. Stott menjelaskan bahwa Allah kita adalah Allah atas segala sesuatu artinya bahwa segala sesuatu adalah sacral dalam arti bahwa semua adalah milik Allah, tidak ada sesuatu yang sekuler maksudnya tidak ada sesuatu yang tak ada sangkut pautnya dengan Allah. Kita harus mensyukuri atas karunia Allah yang sangat besar ini. God is starting point and God is ending point.

Kedua, doktrin yang lebih genap tentang manusia. Karena semua pekerjaan filantropis kita (artinya pekerjaan yang diilhami oleh kasih sayang kepada ma- 
nusia) tergantung dari penilaian kita terhadap manusia maka semakin tinggi kita menilai manusia semakin besar minat kita melayani mereka. Itulah sebabnya ketika Agustinus ditanya, "apakah yang engkau ingin ketahui dalam hidup ini?" jawabannya ialah, yang ingin aku ketahui dalam hidup ini hanya dua hal yaitu mengenal Allah dan mengenal manusia.

Ketiga, doktrin yang lebih genap tentang Kristus. Ada beberapa tanggapan, pendapat dan tafsiran tentang Yesus. Memang wajar jika setiap generasi, orang Kristen berusaha menyelami arti Kristus dan masing-masing menampilkannya melalui pengertian-pengertian yang cocok bagi zaman dan kebudayaannya. Demikianlah kita lihat Yesus dilukiskan sebagai pelaku askese, penderita, raja, pria kesatria, superstar, kapitalis, sosialis, revolusioner, gerilyawan, dan obat ajaib. Beberapa lukisan itu tentu saling bertentangan dan yang sama sekali tidak mempunyai dasar historis. Itulah sebabnya kita perlu menemukan lukisan yang otentik dari Dia yang disebut Kristus yang historis dan alkitabiah. Kita harus melihat Dia dalam segala kegenapan-Nya yang paradoksal yaitu penderitaan-Nya, kemuliaan-Nya, status-Nya sebagai hamba, raja, dan sebagai manusia.

Keempat, doktrin yang lebih genap tentang keselamatan. Stott menulis bahwa kita tidak boleh memisahkan keselamatan dari kerajaan Allah, Yesus sebagai juruselamat dan sebagai Tuhan, dan iman dari kasih. Kita mempunyai tekanan yang seimbang antara keselamatan masa lalu, sekarang, dan yang akan datang.

Dan akhirnya, doktrin yang lebih genap tentang gereja. Dalam hal ini Stott menekankan tentang jati diri gereja yang ganda. Di satu pihak gereja adalah umat kudus, yang dipanggil Allah menjadi milik-Nya, tetapi di pihak lain gereja adalah suatu jemaat yang duniawi dalam arti bahwa mereka adalah orang-orang yang diutus kembali ke dalam dunia untuk bersaksi dan melayani. Istilah Bonhoeffer keduniawian yang saleh dari gereja. Tuhan Yesus mengistilahkan dalam dunia, tetapi bukan dari dunia. ${ }^{16}$

\section{(Innotes)}

1 Mahasiswa Program Pascasarjana pada STT Jaffray Makassar.

${ }^{2}$ Di sini tidak menggunakan istilah "Post Modernisme" karena penulis melihat sebagai gejala yang sedang merasuk dalam pikiran masyarakat saat ini, meskipun post modern mengandung filsafat hidup oleh para penganutnya.

${ }^{3}$ Stanley J. Grenz, Postmodernism;Sebuah Pengenalan atau dapat dilihat dalam situs:

http//: www. sabda.org/reformed/theologi praktika/etos postmodern.

4 John Naisbitt, Megatrends 2000, (Jakarta: Binarupa Aksara, 1990), 266.

${ }^{5}$ Kalvin Surya, "Post Modern dan Pengaruhnya bagi Kekristenan" atau dapat di lihat dalam situs: http://www.lrii.or.id

${ }^{6}$ Gene Veith, Post Modern Times dalam Kalvin Surya "Post Modern dan Pengaruhnya Bagi Kekristenan".

7 Harry Blamires, The Post Christian Mind. Mengenali Perlawanan Terhadap Wawasan Kristen. (Jakarta: Momentum, 2003), 199, 203.

8 Rick Warren, Pertumbuhan Gereja Masa Kini. (Malang: Gandum Mas, 1999), 214.

9 Alastair V. Campbell ed., A Dictionary of Pastoral Care. (London: SPCK Holy Trinity Church, 1987), 41-42.

${ }^{10} \mathrm{John}$ Powell dan Loretta Brady, Tampilkan Jati Dirimu. (Yogyakarta: Kanisius, 1991), 137.

${ }^{11}$ Stephen R. Covey, 7 Kebiasaan Manusia Yang Sangat Efektif. (Jakarta: Binarupa Aksara, 1994), 235.

${ }^{12}$ Joseph Thayer, Thayer's Greek-English Lexicon of the New Testament. (Hedrickson Publisher, 1996),5384.

${ }^{13}$ Rick Warren, The Purpose Driven Life: Kehidupan Yang Digerakkan oleh Tujuan. (Malang: Gandum Mas, 2004), 168.

${ }^{14}$ Terjemahan The Message dari Kitab Amsal 16:28. 
${ }^{15}$ Lyle E. Schaller, It's A Different World. The Challenge For Today's Pastor (Nashville: Abington Press, 1987), 21.

${ }^{16}$ John Stott, Isu-Isu Global Menantang Kepemimpinan Kristiani. (Jakarta: Yayasan omunikasi Bina Kasih/OMF, 1994), 1-22.

\section{BIBLIOGRAPHY}

Stott, John. Isu-Isu Global Menantang Kepemimpinan Kristiani. Jakarta: Yayasan Komunikasi Bina Kasih/ OMF, 1994.

Surya, Kalvin. Post Modern dan Pengaruhnya bagi Kekristenan" atau dapat di lihat dalam situs: http://www.Irii.or.id.

John Naisbitt, Megatrends 2000, Jakarta: Binarupa Aksara, 1990.

Veith, Gene. Post Modern Times dalam Kalvin Surya "Post Modern dan Pengaruhnya Bagi Kekristenan".

Blamires, Harry. The Post Christian Mind. Mengenali Perlawanan Terhadap
Wawasan Kristen. Jakarta: Momentum, 2003.

Schaller, Lyle E. It's A Different World. The Challenge For Today's Pastor Nashville: Abington Press, 1987.

Warren, Rick. The Purpose Driven Life: Kehidupan Yang Digerakkan oleh Tujuan. Malang: Gandum Mas, 2004.

Pertumbuhan Gereja Masa Kini. Malang: Gandum Mas, 1999.

Thayer, Joseph. Thayer's Greek-English Lexicon of the New Testament. Hedrickson Publisher, 1996.

Powell, John dan Loretta Brady, Tampilkan Jati Dirimu. Yogyakarta: Kanisius, 1991.

Covey, Stephen R. 7 Kebiasaan Manusia yang Sangat Efektif. Jakarta: Binarupa Aksara, 1994.

Campbell, Alastair V. ed. A Dictionary of Pastoral Care. London: SPCK Holy Trinity Church, 1987. 